\title{
FAKTOR-FAKTOR YANG MEMPENGARUHI PERMINTAAN DAGANG SAPI POTONG DI KOTA POLOPO
}

\author{
Hasbi Munarka, MS ${ }^{1}$, Samsul Bachri ${ }^{2}$, Askar $^{3}$ \\ 1) Dosen Sekolah Tinggi Ilmu Ekonomi Muhammadiyah Palopo \\ ${ }^{2,3)}$ Dosen Sekolah Tinggi Ilmu Ekonomi Muhammadiyah Palopo
}

\begin{abstract}
Abstrak: Penelitian ini bertujuan untuk mengetahui faktor-faktor yang mempengaruhi permintaan daging sapi di Kota palopo

Variabel independen dalam penelitian adalah harga daging sapi, harga daging ayam, pendapatan, jumlah anggota keluarga dan selera sedangkan variabel dependen yaitu permintaan daging sapi potong. Pengumpulan data dilakukan dengan mengumpulkan dan mempelajari dokumen-dokumen yang dibutuhkan dalam menunjang hasil penelitian ini. Selanjutnya data hasil penelitian dianilisis dengan menggunakan metode analisis regresi linear sederhana dengan menggunakan bantuan program Statistical Product and Service Solution (SPSS) Versi 17.

Hasil analsis data menujukkan bahwa secara bersama-sama variabel harga daging sapi, harga daging ayam, pendapatan, jumlah anggota keluarga dan selera berpengaruh signifikan terhadap permintaan daging sapi dengan persentase sebesar 99,1\%. Nilai signifikansi untuk variabel harga daging sapi sebesar 0,124 >0,10, maka dapat disimpulkan bahwa variabel harga daging sapi tidak berpengaruh secara signifikan terhadap permintaan daging sapi potong. Nilai signifikansi untuk variabel harga barang subtitusi signifikansi sebesar 0,000 <0,10, maka dapat disimpulkan bahwa variabel harga barang subtitusi berpengaruh secara signifikan terhadap permintaan daging sapi potong. Nilai signifikansi untuk variabel pendapatan sebesar 0,000 $<0,10$, maka dapat disimpulkan bahwa variabel pendapatan berpengaruh secara signifikan terhadap permintaan daging sapi potong. Nilai signifikansi untuk variabel jumlah anggota keluarga sebesar 0,722 >0,10, maka dapat disimpulkan bahwa variabel jumlah anggota keluarga tidak berpengaruh secara signifikan terhadap permintaan daging sapi potong. Nilai signifikansi untuk variabel selera sebesar 0,493 > 0,10, maka dapat disimpulkan bahwa variabel selera tidak berpengaruh secara signifikan terhadap permintaan daging sapi potong.
\end{abstract}

Kata Kunci: Permintaan daging sapi, harga daging sapi, hara daging ayam, pendapatan, jumlah anggota keluarga dan selera.

\section{PENDAHULUAN}

Pengembangan usaha sub sektor peternakan merupakan salah satu bagian yang terintegral dengan pembangunan sektor pertanian dalam upaya pengembangan dan peningkatan ekonomi bangsa dan negara. Pengembangan usaha sub sektor peternakan sebagai salah satu upaya dalam pemenuhan kebutuhan masyarakat akan kebutuhan protein hewani.

Daging merupakan salah satu sumber protein hewani yang bersumber dari hewan ternak. Daging dapat dihasilkan dari berbagai komoditas peternakan seperti ternak besar, ternak kecil dan ternak unggas. Ternak besar seperti sapi merupakan salah satu jenis ternak yang memilki peranan penting sebagai penghasil daging dengan kualitas dan kuantitas cukup baik. Jenis atau bangsa sapi yang terdapat di Indonesia sebagai penghasil daging adalah sapi potong seperti bangsa sapi Bali, sapi Madura, sapi Peranakan Ongole (PO), sapi Brahman Cross dan lain-lain.

Pemenuhan kebutuhan protein hewani masyarakat berkaitan erat dengan suplai daging dalam negeri. Saat ini, permintaan daging dalam negeri masih belum diimbangi oleh suplai yang memadai. Menurut Asosiasi Produsen Daging dan Feedlot Indonesia (APFINDO), pada tahun 2013 kebutuhan daging nasional sebesar 399.535 ton. Dari kebutuhan tersebut, sebanyak 66,2 \% 
dipenuhi dari pemotongan sapi-sapi lokal, selebihnya dipenuhi dari impor daging, jeroan, dan sapi bakalan. Total impor daging tahun 2012 mencapai 75.000 ton dan naik menjadi 120.000 ton pada tahun 2013. Sementara itu, jumlah penduduk Indonesia pada tahun 2013 sekitar 237 juta jiwa. Jumlah ini dari tahun ke tahun cenderung bertambah. Kondisi ini tentu saja menjadikan kebutuhan protein hewani juga bertambah.

Daging digolongkan sebagai salah satu produk peternakan penghasil bahan pangan. Bahan pangan adalah bahan yang dimakan sehari-hari atau sewaktu-waktu untuk memenuhi kebutuhan bagi pemeliharaan, pertumbuhan dan pengganti kebutuhan jaringan yang rusak (Suhardjo 2000:22). Bahan pangan merupakan penghasil lemak, energi, sumber kalori untuk menyuplai energi dari dalam (Buckle, 2000:11). Daging memiliki kandungan protein yang berguna dalam memenuhi standar konsumsi masyarakat terhadap daging, standar konsumsi kebutuhan protein pada anak balita 2 - 2,5 gram per kilogram berat badan, sedangkan pada orang dewasa hanya 1 gram per kilogram berat badan. (Rasyaf, 2000:22). Di sisi lain dengan pertumbuhan penduduk dan pertumbuhan ekonomi yang meningkat meningkat setiap tahunnya mengakibatkan konsumsi daging sapi pun meningkat dari tahun ke tahun.

Dari tahun ke tahun di daerah Sulawesi Selatan, jumlah penduduknya cenderung mengalami peningkatan, namun konsumsi daging cenderung mengalami penurunan, dengan bertambahnya jumlah penduduk seharusnya berdampak pada konsumsi daging yang meningkat pula akan tetapi kenyataannya tidak demikian.

\section{BAHAN DAN METODE}

Jenis data yang digunakan pada penelitian ini adalah data kuantitatif adalah data yang berbentuk angka-angka meliputi data harga daging sapi potong, harga barang subtitusi, pendapatan masyarakat, jumlah anggota keluarga, selera dan permintaan daging sapi potong potong.

Sumber data yang digunakan pada penelitian ini adalah Data primer yaitu data yang bersumber dari hasil wawancara atau interview langsung dengan responden meliputi data identitas responden antara lain: umur, pekerjaan, pendidikan, pendapatan, jumlah anggota keluarga, harga jual daging sapi potong, harga barang subtitusi, selera masyarakat terhadap daging sapi potong dan permintaan daging sapi potong potong. Data sekunder yaitu data yang bersumber dari laporan-laporan, kepustakaan, dinas yang terkait, kantor kelurahan, Badan Pusat Statistik.

Populasi dalam penelitian adalah keseluruhan penduduk Kota Palopo yang melakukan pembelian daging sapi. Berdasarkan data dari Badan Pusat Statistik Kota Palopo dalam Kota Palopo dalam Angka 2014 jumlah penduduk Kota Palopo adalah 160.819 jiwa. sampel dalam penelitian berjumlah 100 responden.

Metode pengumpulan data yang digunakan yaitu obserpasi dan wawancara. Alat analisis yang digunakan dalam penelitian ini adalah statistik inferensial yaitu Regresi Linear Berganda yang bertujuan untuk mengetahui/memprediksi adanya pengaruh harga daging sapi, harga barang subtitusi, pendapatan masyarakat, jumlah anggota keluarga dan selera terhadap permintaan daging sapi potong potong di Kota Palopo. Analisis data 
dalam penelitian dilakukan dengan menggunakan bantuan program SPSS 17 for windows.

Adapun persamaan dari Regresi Berganda adalah sebagai berikut (Algifari, 2000) :

$Y=a+b_{1} X_{1}+b_{2} X_{2}+b_{3} X_{3}+b_{4} X_{4}+b_{4} X_{4}+b_{5} X_{5}$

$+\mathrm{e}$

Keterangan :

$\mathrm{Y}=$ Permintaan daging sapi potong Potong di Kota Palopo

$\mathrm{a}=$ Konstanta

$\mathrm{b}=$ Koefisien regresi variabel bebas

$\mathrm{X}_{1}=$ Variabel Harga Daging Sapi (Rupiah)

$\mathrm{X}_{2}=$ Variabel Harga Barang Subtitusi (Rupiah)

$\mathrm{X}_{3}=$ Variabel Pendapatan Masyarakat (Rupiah)

$\mathrm{X}_{4}=$ Variabel Jumlah Anggota Keluarga (Orang)

$\mathrm{X}_{5}=$ Variabel Selera

e $=$ Standard Error

\section{HASIL DAN PEMBAHASAN}

\section{Analisis Data Penelitian}

\section{Analisis Regresi Linear Berganda}

Untuk mengetahui pengaruh harga daging sapi, harga barang subtitusi, pendapatan, jumlah anggota keluarga dan selera terhadap permintaan daging sapi potong di Kota Palopo, digunakan analisis regresi berganda.

\section{Coefficients $^{\mathrm{a}}$}

\begin{tabular}{|c|c|c|c|c|c|c|}
\hline & & \multicolumn{2}{|c|}{$\begin{array}{c}\text { Unstandardized } \\
\text { Coefficients }\end{array}$} & $\begin{array}{c}\text { Standardized } \\
\text { Coefficients }\end{array}$ & \multirow[b]{2}{*}{$\mathrm{t}$} & \multirow[b]{2}{*}{ Sig. } \\
\hline \multicolumn{2}{|c|}{ Model } & $\mathrm{B}$ & Std. Error & Beta & & \\
\hline 1 & (Constant) & .244 & .119 & & 2.044 & .044 \\
\hline & Harga. Dg. Sapi & -.048 & .031 & -.040 & -1.552 & .124 \\
\hline & Harga Brg.Sub. & .993 & .020 & .760 & 49.208 & .000 \\
\hline & Pendapatan & .461 & .081 & .426 & 5.704 & .000 \\
\hline & Jml. Angg.Keluarga & .025 & .070 & .023 & .357 & .722 \\
\hline & Selera & .026 & .037 & .031 & .688 & .493 \\
\hline
\end{tabular}

a. Dependent Variable: Permintaan Daging Sapi 
Berdasarkan Tabel di atas, mka diperoleh persamaan analisis regresi linear berganda sebagai sebagai berikut:

$\mathrm{Y}=0,244-0,048 \mathrm{X} 1+0,993 \mathrm{X} 2+0,461 \mathrm{X} 3+$

$$
0,025 \mathrm{X} 4+0,026 \mathrm{X} 5+\mathrm{e}
$$

Dari persamaan regresi linear berganda tersebut di atas, maka dapat disimpulkan bahwa:

a. Apabila nilai koefisien harga daging sapi, harga barang subtitusi, pendapatan, jumlah anggota masyarakat dan selera sama dengan nol maka besarnya permintaan daging sapi potong adalah $0,244 \mathrm{Kg}$.

b. Nilai koefisien regresi untuk harga daging sapi sama dengan $-0,048$, berarti bahwa apabila harga daging sapi dinaikkan sebesar Rp. 1, maka akan berpengaruh penurunan permintaan daging sapi potong sebesar 0,048 $\mathrm{Kg}$.

c. Nilai koefisien regresi untuk harga barang subtitusi sama dengan 0,993, berarti bahwa setiap peningkatan harga barang subtitusi sebesar Rp. 1, maka akan mempengaruhi peningkatan permintaan daging sapi potong sebesar 0,993 Kg. d. Nilai koefisien regresi untuk harga pendapatan sama dengan 0,461 , berarti bahwa setiap peningkatan pedapatan sebesar Rp. 1, maka akan mempengaruhi peningkatan permintaan daging sapi potong sebesar 0,461 $\mathrm{Kg}$.

e. Nilai koefisien regresi untuk jumlah anggota keluarga sama dengan 0,025 , berarti bahwa setiap peningkatan jumlah anggota keluarga sebanyak 1 orang, maka akan mempengaruhi peningkatan permintaan daging sapi potong sebesar $0,025 \mathrm{Kg}$.

\section{Analisis Koefisien Determinasi}

Analisis koefisien determinasi digunakan untuk mengetahui persentase pengaruh secara bersama variabel bebas terhadap variabel terikat dalam penelitian.

Model Summary

\begin{tabular}{|c|c|c|c|c|c|c|c|c|c|}
\hline \multirow[b]{2}{*}{ Model } & \multirow[b]{2}{*}{$\mathrm{R}$} & \multirow[b]{2}{*}{ R Square } & \multirow[b]{2}{*}{$\begin{array}{l}\text { Adjusted R } \\
\text { Square }\end{array}$} & \multirow[b]{2}{*}{$\begin{array}{l}\text { Std. Error of the } \\
\text { Estimate }\end{array}$} & \multicolumn{5}{|c|}{ Change Statistics } \\
\hline & & & & & $\begin{array}{l}\text { R Square } \\
\text { Change }\end{array}$ & $\begin{array}{c}\mathrm{F} \\
\text { Change }\end{array}$ & df1 & df2 & $\begin{array}{l}\text { Sig. F } \\
\text { Change }\end{array}$ \\
\hline 1 & $.996^{\mathrm{a}}$ & .991 & .991 & .138 & .991 & 2149.878 & 5 & 94 & .000 \\
\hline
\end{tabular}

a. Predictors: (Constant), Selera, Harga Brg.Sub., Harga Daging Sapi, Jml. Angg.Keluarga, Pendapatan 
Dari Tabel di atas, diketahui bahwa nilai $\mathrm{R}$ sebesar 0,996 berarti bahwa variabel independen dan variabel dependen dalam penilitan ini mempunyai korelasi yang sangat tinggi dan nilai $\mathrm{R}$ Square sebesar 0,991, berarti bahwa persentase pengaruh harga daging sapi, harga barang subtitusi, pendapatan, jumlah anggota keluarga dan selera berpengaruh sebesar $99,1 \%$ terhadap permintaan daging sapi potong dan sisanya sebesar $0,9 \%$ dipengaruhi oleh faktor lain yang tidak diteliti dalam penelitian ini.

\section{Uji t (Parsial)}

Uji $\mathrm{t}$ ini digunakan untuk mengetahui apakah masing-masing variabel bebasnya secara sendiri-sendiri berpengaruh secara signifikan terhadap variabel terikatnya. Untuk uji t dengan tingkat kepercayaan $90 \%(\alpha \quad 0.10)$, penarikan kesimpulan dilakukan berdasarkan taraf singnifikansi dengan kriteria sebagai berikut:

1) Apabila signifikasi $>0,10$, maka variabel harga daging sapi, harga barang subtitusi, pendapatan, jumlah anggota keluarga dan selera masing-masing tidak berpengaruh secara signifikan tehadap perminataan daging sapi.

2) Apabila signifikansi $<0,10$ maka variabel harga daging sapi, harga barang subtitusi, pendapatan, jumlah anggota keluarga dan selera masing-masing berpengaruh secara signifikan tehadap perminataan daging sapi.

Dari Tabel Coefficients di atas, maka dapat kita tarik simpulan sebagai berikut:

1) Untuk variabel harga daging sapi signifikansi sebesar 0,124>0,10, maka dapat disimpulkan bahwa variabel harga daging sapi tidak berpengaruh secara signifikan terhadap permintaan daging sapi potong.

2) Untuk variabel harga barang subtitusi diperoleh signifikansi sebesar $0,000<0,10$, maka dapat disimpulkan bahwa variabel harga barang subtitusi berpengaruh secara signifikan terhadap permintaan daging sapi potong.

3) Untuk variabel pendapatan signifikansi diperoleh sebesar $0,000<0,10$, maka dapat disimpulkan bahwa variabel pendapatan berpengaruh secara signifikan terhadap permintaan daging sapi potong.

4) Untuk variabel jumlah anggota keluarga diperoleh signifikansi sebesar $0,722>0,10$, maka dapat disimpulkan bahwa variabel jumlah anggota keluarga tidak berpengaruh secara signifikan terhadap permintaan daging sapi potong.

5) Untuk variabel selera diperoleh signifikansi sebesar 0,493 > 0,10, maka dapat disimpulkan bahwa variabel selera tidak berpengaruh secara signifikan terhadap permintaan daging sapi potong.

\section{Uji F (Uji Serempak)}

Uji ini digunakan untuk mengetahui pengaruh bersama-sama variabel bebas terhadap varibel terikat. Untuk uji $\mathrm{F}$ dengan tingkat kepercayaan 90\% ( $\alpha 0.10)$, penarikan kesimpulan dilakukan berdasarkan taraf signifikansi dengan kriteria sebagai berikut:

1) Apabila signifikasi $>0,10$ Tabel maka variabel harga daging sapi, harga barang subtitusi, pendapatan, jumlah anggota keluarga dan selera secara bersama-sama 
tidak berpengaruh secara signifikan tehadap perminataan daging sapi.

2) Apabila signifikansi $<0,10$ maka variabel harga daging sapi, harga barang subtitusi, pendapatan, jumlah anggota keluarga dan selera secara bersama-sama berpengaruh secara signifikan tehadap permintaan daging sapi potong.

ANOVA $^{b}$

\begin{tabular}{|c|c|c|c|c|c|}
\hline Model & $\begin{array}{l}\text { Sum of } \\
\text { Squares }\end{array}$ & $\mathrm{df}$ & $\begin{array}{l}\text { Mean } \\
\text { Square }\end{array}$ & $\mathrm{F}$ & Sig. \\
\hline $\begin{array}{l}1 \text { Regressi } \\
\text { on }\end{array}$ & 203.927 & 5 & 40.785 & $\begin{array}{r}2149 . \\
878\end{array}$ & $.000^{\mathrm{a}}$ \\
\hline Residual & 1.783 & 94 & .019 & & \\
\hline Total & 205.710 & 99 & & & \\
\hline
\end{tabular}

a. Predictors: (Constant), Selera, Harga Brg.Sub., Harga Daging Sapi, Jml. Angg.Keluarga, Pendapatan b. Dependent Variable: Permintaan Daging Sapi

Dari Tabel di atas diketahui bahwa nilai signifikansi sebesar $0,000<0,10$, maka dapat disimpulkan bahwa variabel harga daging sapi, harga barang subtitusi, pendapatan, jumlah anggota keluarga dan selera secara bersama-sama berpengaruh secara signifikan terhadap permintaan daging sapi potong.

\section{Pembahasan}

Berdasarkan hasil analisis data di atas, maka dapat disimpulkan bahwa secara bersama-sama variabel harga daging sapi, harga barang subtitusi, pendapatan, jumlah anggota keluarga dan selera berpengaruh secara signifikan terhadap permintaan daging sapi potong. Hal ini dibuktikan dengan uji hipotesis dengan uji $\mathrm{F}$ diperoleh nilai signifikansi sebesar $0,000<0,10$. Nilai $\mathrm{R}$ Square diperoleh sebesar 0,991, berarti bahwa persenntase pengaruh harga daging sapi, harga barang subtitusi, pendapatan, jumlah anggota keluarga dan selera berpengaruh sebesar $99,1 \%$ terhadap permintaan daging sapi potong dan sisanya sebesar $0,9 \%$ dipengaruhi faktor-faktor lain yang tidak diteliti dalam penelitian ini.

Hasil uji hipotesis dengan uji t diperoleh kesimpulan sebagai berikut:

1) Untuk variabel harga daging sapi signifikansi sebesar 0,124 >0,10, maka dapat disimpulkan bahwa variabel harga daging sapi tidak berpengaruh secara signifikan terhadap permintaan daging sapi potong.

2) Untuk variabel harga barang subtitusi diperoleh signifikansi sebesar $0,000<0,10$, maka dapat disimpulkan bahwa variabel harga barang subtitusi berpengaruh secara signifikan terhadap permintaan daging sapi potong.

3) Untuk variabel pendapatan signifikansi diperoleh sebesar $0,000<0,10$, maka dapat disimpulkan bahwa variabel pendapatan berpengaruh secara signifikan terhadap permintaan daging sapi potong.

4) Untuk variabel jumlah anggota keluarga diperoleh signifikansi sebesar $0,722>0,10$, maka dapat disimpulkan bahwa variabel jumlah anggota keluarga tidak berpengaruh secara signifikan terhadap permintaan daging sapi potong.

5) Untuk variabel selera diperoleh signifikansi sebesar 0,493>0,10, maka dapat disimpulkan bahwa variabel selera tidak berpengaruh secara signifikan terhadap permintaan daging sapi potong. 


\section{SIMPULAN}

1) Secara bersama-sama variabel harga daging sapi, harga ikan, pendapatan, jumlah anggota keluarga dan selera berpengaruh signifikan terhadap permintaan daging sapi potong dengan persentase sebesar $99,1 \%$.

2) Nilai signifikansi untuk variabel harga daging sapi sebesar 0,124>0,10, maka dapat disimpulkan bahwa variabel harga daging sapi tidak berpengaruh secara signifikan terhadap permintaan daging sapi potong.

3) Nilai signifikansi untuk variabel harga barang subtitusi signifikansi sebesar $0,000<0,10$, maka dapat disimpulkan bahwa variabel harga barang subtitusi berpengaruh secara signifikan terhadap permintaan daging sapi potong.

4) Nilai signifikansi untuk variabel pendapatan sebesar $0,000<0,10$, maka dapat disimpulkan bahwa variabel pendapatan berpengaruh secara signifikan terhadap permintaan daging sapi potong.

5) Nilai signifikansi untuk variabel jumlah anggota keluarga sebesar 0,722 >0,10, maka dapat disimpulkan bahwa variabel jumlah anggota keluarga tidak berpengaruh secara signifikan terhadap permintaan daging sapi potong.

6) Nilai signifikansi untuk variabel selera sebesar 0,493>0,10, maka dapat disimpulkan bahwa variabel selera tidak berpengaruh secara signifikan terhadap permintaan daging sapi potong.

\section{DAFTAR PUSTAKA}

Algifari. 2000. Analisis Regresi. Yogyakarta: BPFE
Amirullah. 2002. Perilaku Konsumen. Graha Ilmu. Yogyakarta

Anonim.2011.Makassar Dalam Angka 2011. Badan Pusat Statistika. Makassar.

2011.Palopo Dalam Angka 2014. Badan Pusat Statistika. Palopo. .. 2012. Bahan Makanan. Depkes: Jakarta.

Anwar, Khairil. 2011. Analisis Pola Konsumsi Masyarakat Pedesaan di kabupaten BireuenAceh.

Assauri, S. 1987. Manajemen Pemasaran Konsep Dasar dan Strategi. Rajawali Press. Jakarta

Braudrilland, Jean. 2004. Masyarakat Konsumtif. Yogyakarta: Kreai Wacana.

Buckle. B.A. 2000. Ilmu Pangan. Direktorat Jenderal Pendidikan Tinggi Departemen Pendidikan dan Kebudayaan. Jakarta.

Chaney, Robert. 2003. Perilaku Konsumen (Bandung: Pustaka Karya.

Delorme, C.D. and Ekulend, R.B. 1993.Macroeconomics. PBI Inc. Texas

Gilarso, T. 2004. Pengantar Ilmu Ekonomi Mikro. Yogyakarta: Kanisius.

Hidayat, S. 2004. Analisis Permintaan Konsumen Keluarga Terhadap Telur Ayam Ras di Kecamatan Koja Jakarta Utara [Skripsi] Bogor: Institut Pertanian Bogor; Fakultas Pertanian.

Kadariah. 1996.Pengantar Teori Ekonomi Makro. Bina Aksar. Jakarta

Karyadi dan Muhillal. , 2000. Strategi Pemasaran Daging Sapi. Bandung: Alfabeta.

Kotler, P. 2000. Dasar-Dasar Pemasaran. Jakarta: Indeks.

1997. Manajemen Pemasaran, Analisis, Perencanaan, Implementasi dan Kontrol. Jilid I. Edisi Bahasa Indonesia. Prehalindo. Jakarta. 
Lipsey G, Richard, et al. 1997. Pengantar Mikroekonomi. Edisi Ke-8 Jilid I. Jakarta: Erlangga.

Miller, Tim. Explaining Keynes Theory of Compsumtion, and Assessing its Strengths and Weaknesses. (Jakarta:Penebar Swadaya, 2006). Penterjemah Alexander Sindoro

Pitomo. 1992. Analisis Pola Konsumsi Rumah Tangga Miskin Pasca Kenaikan Harga BBM Di Kota Makassar.Skripsi, tidak dipublikasikan.

Putong. 2003. Pengantar Ekonomi Mikro dan Makro. Ghalia Indonesia. Jakarta.

Rasyaf, Muhammad. 2000. Memasarkan Hasil Peternakan. Jakarta: Penebar Swadaya.

Rosydi, Suherman. 1996. Pengantar Teori Ekonomi. Raja Grafindo Persada. Jakarta

Salvatore, Dominick. 1994.Ekonomi Pembangunan, Erlangga, Jakarta

Sarjono, Haryadi dan Winda Julianita, 2011.SPSS Vs LISREL: Sebuah Pengantar, Aplikasi Untuk Riset, Jakarta: Salemba Empat.

Soekartawi. 2003. Prinsip Dasar Ekonomi Pertanian Teori dan Aplikasi. Jakarta: Rajawali Pers.

Sugeng, B.2000. Sapi Potong. Jakarta: Penebar Swadaya.

Sugiarto. 2005. Teoari Produksi. Jakarta: Indeks.

Suhardjo. 2000. Kebutuhan Pangan. Jakarta: Erlangga.

Sukirno, Sadono. 2002. Pengantar Teori Ekonomi Mikro. Edisi Ke-3. Jakarta: Pt. Raja Grafindo Persada.

. 2004 Pengantar Teori Ekonomi Mikro. Edisi Ke-5. Jakarta: Pt. Raja Grafindo Persada.

2003. Pengantar Teori Mikro Ekonomi. Jakarta: FE. UI.
Sumarno. 2007. Ekonomi Mikro. PT Graha Ilmu. Yogyakarta.

Suparmoko, Joko. 2000. Wirausaha dalam Globalisasi. Yogyakarta: Liberty.

Umar, Husein. 2001. Metode Penelitian Untuk Skripsi dan Tesis Bisnis. Jakarta, PT Gramedia Pustaka Utama.

Wilson. 2007. Teori Ekonomi Mikro. PT Refika Aditama. Bandung. 